University of Nebraska - Lincoln

DigitalCommons@University of Nebraska - Lincoln

1996

\title{
Sea-level records at $\sim 80$ ka from tectonically stable platforms: Florida and Bermuda
}

\author{
K. R. Ludwig \\ U.S. Geological Survey \\ D. R. Muhs \\ U.S. Geological Survey, dmuhs@usgs.gov \\ K. R. Simmons \\ U.S. Geological Survey, ksimmons@usgs.gov \\ R. B. Halley \\ U.S. Geological Survey \\ E. A. Shinn \\ U.S. Geological Survey
}

Follow this and additional works at: https://digitalcommons.unl.edu/usgsstaffpub

Part of the Earth Sciences Commons

Ludwig, K. R.; Muhs, D. R.; Simmons, K. R.; Halley, R. B.; and Shinn, E. A., "Sea-level records at $~ 80$ ka from tectonically stable platforms: Florida and Bermuda" (1996). USGS Staff -- Published Research. 154.

https://digitalcommons.unl.edu/usgsstaffpub/154

This Article is brought to you for free and open access by the US Geological Survey at DigitalCommons@University of Nebraska - Lincoln. It has been accepted for inclusion in USGS Staff -- Published Research by an authorized administrator of DigitalCommons@University of Nebraska - Lincoln. 


\title{
Sea-level records at $\sim 80$ ka from tectonically stable platforms: Florida and Bermuda
}

\author{
K. R. Ludwig* \\ D. R. Muhs \\ K. R. Simmons \\ R. B. Halley 7 \\ E. A. Shinn $]$ \\ U.S. Geological Survey, MS 963, Box 25046, Federal Center, Denver, Colorado 80225 \\ U.S. Geological Survey, Center for Coastal Geology, 600 4th Street South, St. Petersburg, Florida 33701
}

\section{ABSTRACT}

Studies from tectonically active coasts on New Guinea and Barbados have suggested that sea level at $\sim 80$ ka was significantly lower than present, whereas data from the Atlantic and Pacific coasts of North America indicate an $\sim 80 \mathrm{ka}$ sea level close to that of the present. We determined ages of corals from a shallow submerged reef off the Florida Keys and an emergent marine deposit on Bermuda. Both localities are on tectonically stable platforms distant from plate boundaries. Uranium-series ages show that corals at both localities grew during the $\sim 80$ ka sea-level highstand, and geologic data show that sea level at that time was no lower than 7-9 $\mathrm{m}$ below present (Florida) and may have been 1-2 $\mathrm{m}$ above present (Bermuda). The ice-volume discrepancy of the $80 \mathrm{ka}$ sea-level estimates is greater than the volume of the Greenland or West Antarctic ice sheets. Comparison of our ages with highlatitude insolation values indicates that the sea-level stand near the present at $\sim 80 \mathrm{ka}$ could have been orbitally forced.

\section{INTRODUCTION}

The last interglacial period in its broadest sense has been correlated with all of deepsea oxygen isotope stage $5(\sim 130-80 \mathrm{ka})$. Three $\delta^{18} \mathrm{O}$ minima during stage 5 are generally inferred as reflecting sea-level highstands at $\sim 125 \mathrm{ka}, \sim 105 \mathrm{ka}$, and $\sim 80 \mathrm{ka}$, and are commonly correlated with emergent coral reefs of these ages found on tectonically rising coastlines. Though considerable attention has been given to the oldest, and apparently highest, sea-level stand $(\sim 125$ $\mathrm{ka}$ ), much less study has been made of the younger two. Assuming constant uplift rates, studies on tropical island coasts such as New Guinea calculated that sea level at $\sim 80 \mathrm{ka}$ could have been as high as $-6.6 \mathrm{~m}$ (Bloom and Yonekura, 1985, 1990) or as low as $-19 \pm 5 \mathrm{~m}$ (Chappell and Shackleton, 1986, Table 1) relative to present sea level (Fig. 1). On the basis of data from tectonically rising Barbados, sea-level estimates for $\sim 80 \mathrm{ka}$ vary from $-10 \mathrm{~m}$ to $-18 \mathrm{~m}$ (Bender et al., 1979; Gallup et al., 1994). In the tectonically stable Bahamas, U-series dating of submerged speleothems suggests that at $\sim 80$ $\mathrm{ka}$, sea level was below $-15 \mathrm{~m}$ (Lundberg and Ford, 1994) or below -18 m (Richards et al., 1994). A recent study of deep-sea sediments, using $\mathrm{Mg} / \mathrm{Ca}$ in ostracodes combined with oxygen isotopes in foraminifera, suggests that sea level at $\sim 80 \mathrm{ka}$ could even have been as low as $-60 \mathrm{~m}$ to $-70 \mathrm{~m}$ (Dwyer et al., 1995). However, data from the tec-

\footnotetext{
*Present address: Berkeley Geochronology Center, 2455 Ridge Road, Berkeley, California 94709 .
}

tonically active Pacific coast of North America suggest that sea level at $\sim 80$ ka could have been closer to the present, perhaps around $-1 \mathrm{~m}$ (Muhs et al., 1994). In addition, in tectonically stable Virginia and North Carolina, several corals from the Norfolk and Kempsville Formations (or their equivalents), at elevations of -4 to $+5 \mathrm{~m}$, give AS (alpha-spectrometric) ages ranging from $78 \pm 10 \mathrm{ka}$ to $66 \pm 8 \mathrm{ka}$ (all errors $2 \sigma$ )

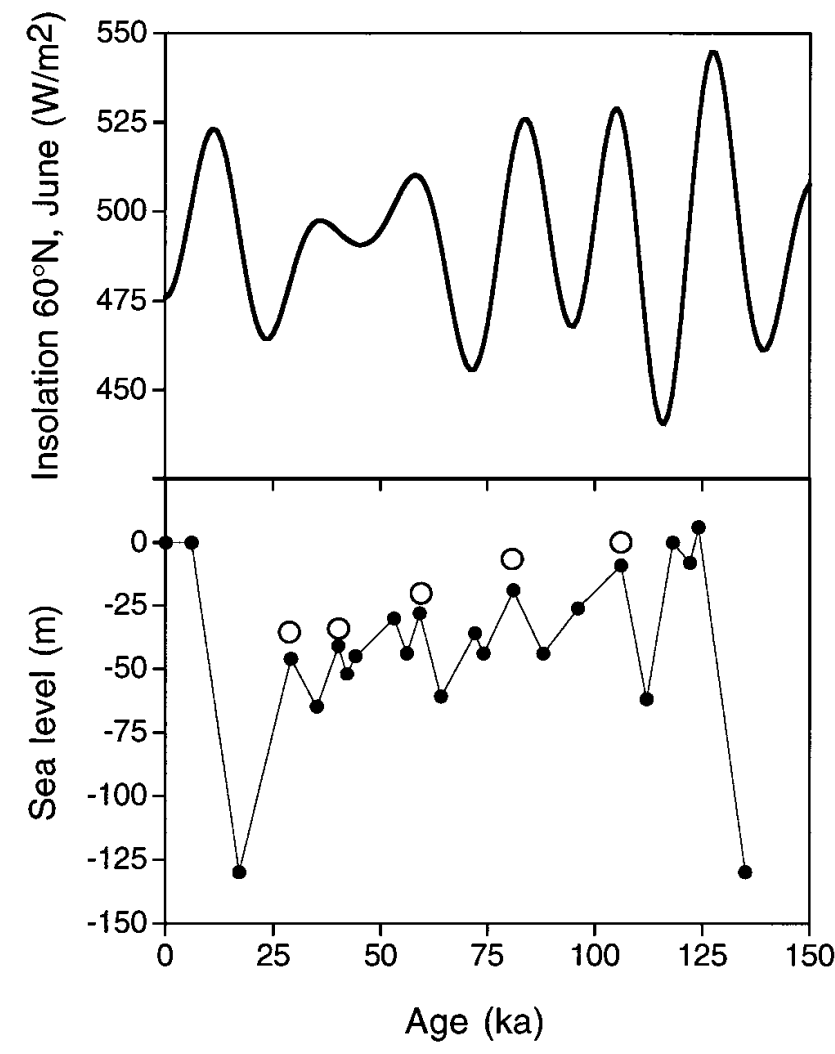

and average about $72 \mathrm{ka}$ (Szabo, 1985). These formations may therefore correlate with the $\sim 80 \mathrm{ka}$ sea-level highstand and, if so, imply a sea level near the present level at that time. Thus there is not a consensus on the position of sea level at $80 \mathrm{ka}$ even among the various coastal records, and the ostracode $\mathrm{Mg} / \mathrm{Ca}$ study implies a vastly different (landbound) ice volume.

Summer insolation values at high latitudes are considered to be critical for the growth and decay of ice sheets according to the orbital forcing theory of climate change (Milankovitch, 1941). The rise toward the 11 ka insolation high is considered to have been the trigger for the decay of the late Wisconsin ice sheets at the close of the last glaciation (Mix, 1987; Ruddiman, 1987). At 84 $\mathrm{ka}$, June insolation at lat $60^{\circ} \mathrm{N}$ was actually higher than at $11 \mathrm{ka}$ (Fig. 1). According to the orbital forcing theory, therefore, insolation at $\sim 84$ ka could have been sufficient to bring about ablation of glacial ice to the extent that sea level rose to the present level.
Figure 1. Comparison of insolation values for June at lat $60^{\circ} \mathrm{N}$ (data from Berger and Loutre, 1991) and sea-level record from coral reefs on tectonically rising New Guinea (solid circles from Chappell and Shackleton, 1986; open circles from Bloom and Yonekura, 1985, 1990). 
$81^{\circ} 50^{\prime} \mathrm{W}$

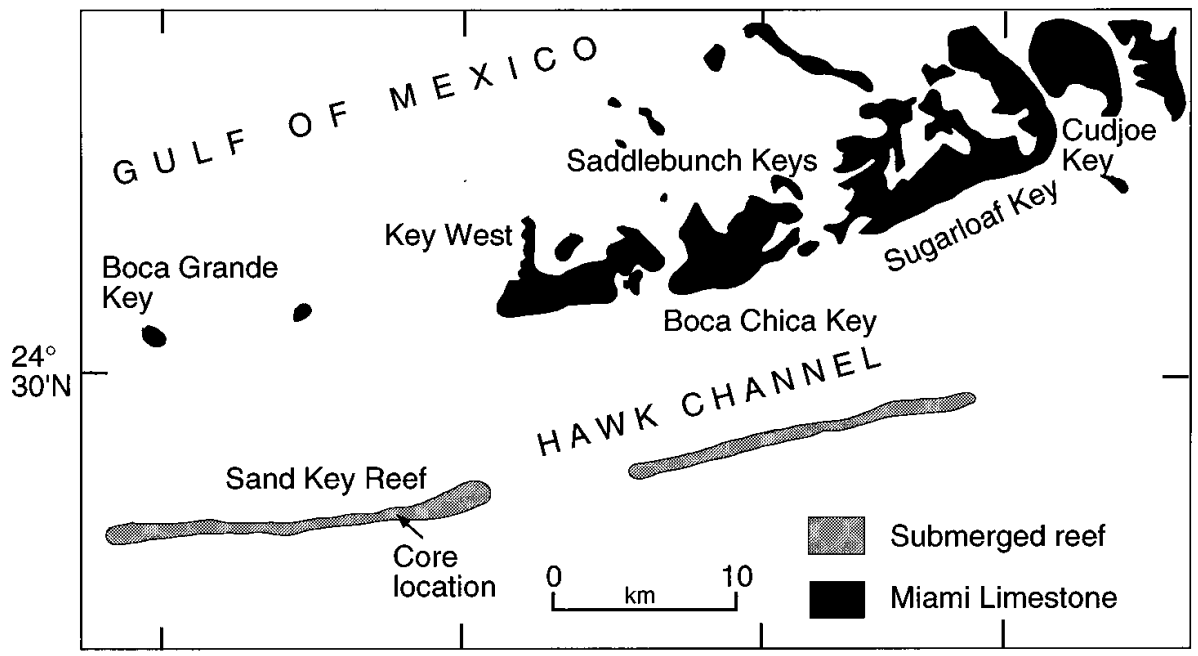

Figure 2. Location of submerged offshore reef south of Florida Keys (black), and sample locality. Reef location data generalized from Lidz et al. (1991).

In order to investigate further the sea level at $\sim 80 \mathrm{ka}$, we studied two localities on the tectonically stable Florida Keys and Bermuda (Figs. 2 and 3), where any sediments deposited at $80 \mathrm{ka}$, whether onshore or offshore, should be unaffected by uplift or subsidence. We report here new ${ }^{230} \mathrm{Th} / \mathrm{U}$ ages of corals from these localities.

\section{URANIUM-SERIES DATING}

All coral samples analyzed are $95 \%-100 \%$ aragonite. Analyses were done by thermal ionization mass spectrometry, as described in Ludwig et al. (1992). All samples have low ${ }^{232} \mathrm{Th}$ contents, indicating negligible initial ${ }^{230}$ Th (Table 1). Although Harmon et al.
(1983) reported ${ }^{234} U{ }^{238} U$ values in living corals from Bermuda that were significantly lower than values reported for modern sea water (e.g., Chen et al., 1986), analyses of two late Holocene corals (Oculina and Siderastrea) that were collected on the modern beach at Shelly Bay, Bermuda, and analyzed in duplicate (Table 1) yield initial ${ }^{234} \mathrm{U} /{ }^{238} \mathrm{U}$ values within $0.25 \%$ of our mean value for other young corals, and agree with modern sea water values. The same is true for a modern Siderastrea (FL-31) collected on the modern beach at Big Pine Key, Florida. With one exception noted below, all fossil corals we analyzed have calculated initial ${ }^{234} \mathrm{U} /{ }^{238} \mathrm{U}$ that are within $0.35 \%$ of values

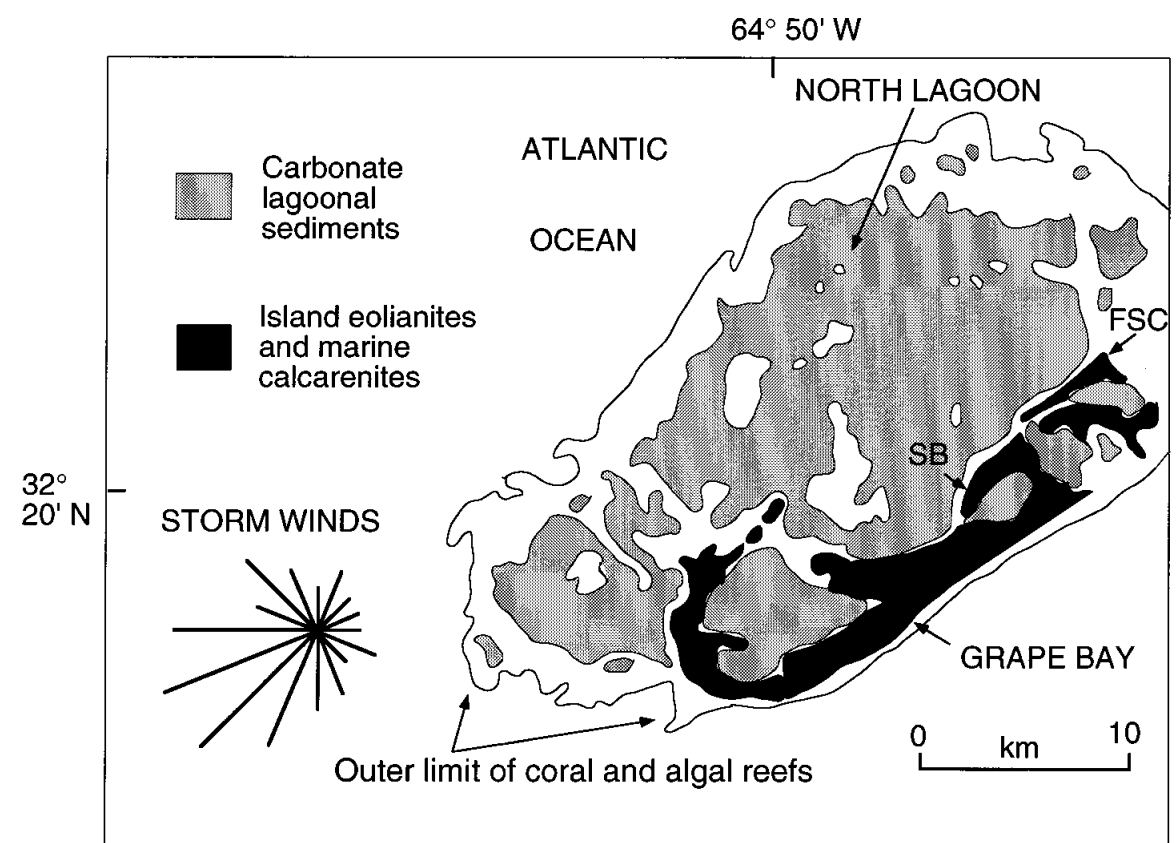

Figure 3. Study localities on island of Bermuda, and distribution of outer reef and lagoon on Bermuda platform (from Vacher et al., 1989). FSC = Fort St. Catherine, SB = Shelly Bay. measured for modern sea water and modern corals (Fig. 4).

\section{FLORIDA KEYS STUDY AREA}

High-resolution seismic-reflection profiles by Lidz et al. (1991) have demonstrated the presence of a submerged outlier-reef tract system extending discontinuously for $\sim 57 \mathrm{~km}$ seaward of the emergent Florida Keys (Fig. 2), formed during the last interglacial. Near Sand Key Reef, $\sim 12$ km southwest of Key West, this feature has multiple, small, outlier reefs, but the main body of the reef has a topographic crest that is $\sim 10-12$ $\mathrm{m}$ below sea level. The reef is dominated by the colonial coral Montastrea annularis, although examination of a core from this reef revealed a thin overgrowth of the reef crest species Acropora palmata, which grows only within $5 \mathrm{~m}$ of sea level. Lidz et al. (1991) reported a radiocarbon age of $>38 \mathrm{ka}$ for a Montastrea sample collected from one of their cores. We determined ${ }^{230} \mathrm{Th} / \mathrm{U}$ ages of samples of Montastrea annularis and Acropora palmata from two newly acquired cores.

Results from the submerged reef off the Florida Keys confirm the earlier $>38$ ka radiocarbon result of Lidz et al. (1991) and indicate that the Montastrea corals in this reef grew during the $\sim 80 \mathrm{ka}$ sea-level highstand (Table 1). A sample (FL-23) of this coral from a core depth of $1.2 \mathrm{~m}$ gives an age of $80.9 \pm 1.7 \mathrm{ka}$, and a sample (FL-20) from a depth of $5.5 \mathrm{~m}$ in the same core gives a stratigraphically consistent age of $83.2 \pm 0.9$ ka. In an adjacent core, a sample of Montastrea (FL-33) from a core depth of $3.5 \mathrm{~m}$ gives an apparent age of $\sim 87 \mathrm{ka}$, but its initial ${ }^{234} \mathrm{U} /{ }^{238} \mathrm{U}$ is much higher (1.1733) than modern sea water, indicating an open-system history. A sample (FL-32) of Acropora palmata from this latter core, taken from $0.1 \mathrm{~m}$ below the core top, gives an age of $8.2 \mathrm{ka}$, showing that this colony is a Holocene overgrowth on the $\sim 80 \mathrm{ka}$ coral.

\section{BERMUDA STUDY AREA}

The island of Bermuda (Fig. 3) has a core of pre-Quaternary volcanic rocks derived from the Mid-Atlantic Ridge, but its surficial deposits are Quaternary carbonatesmostly eolianite, but also consisting of isolated sublittoral marine and beach deposits and some emergent, fossil patch reefs (Vacher et al., 1989). Most of the marine facies have been mapped as belonging to the Belmont Formation (penultimate interglacial age) or the Devonshire marine member of the Rocky Bay Formation (last interglacial age); AS ${ }^{230} \mathrm{Th} / \mathrm{U}$ ages of corals from these formations are about $200 \mathrm{ka}$ and 125 ka, respectively (Harmon et al., 1983). Both formations have eolianite facies that overlie 
the marine facies. An eolianite unit that is slightly younger than the Rocky Bay Formation, called the Southhampton Formation, can be differentiated from the Rocky Bay Formation on the basis of stratigraphic relations (Vacher and Hearty, 1989) and amino-acid racemization data (Hearty et al., 1992). At least three Southampton Formation localities on Bermuda have fossil-bearing marine facies 1-2 $\mathrm{m}$ above sea level, where mollusks yield amino-acid ratios that are lower (i.e., younger) than those found in shells from the marine facies of the slightly older Rocky Bay Formation (Vacher and Hearty, 1989). In addition, Harmon et al. (1983) reported a single $\mathrm{AS}{ }^{230} \mathrm{Th} / \mathrm{U}$ age of $85 \pm 12$ ka for an Oculina sp. coral collected from a Southampton marine facies near Fort St. Catherine, though the significance of this age has been disputed (Harmon et al., 1983; Vacher and Hearty, 1989).

We examined the locality at Fort St. Catherine, collected fossil Oculina corals for dating, and studied the marine facies of the older Rocky Bay Formation at Grape Bay for comparison. Our analyses of Oculina corals from the $+1 \mathrm{~m}$ to $+2 \mathrm{~m}$ marine deposit at Fort St. Catherine on Bermuda give ${ }^{230} \mathrm{Th} / \mathrm{U}$ ages of $82.3 \pm 3.6 \mathrm{ka}, 82.4 \pm 0.9 \mathrm{ka}$, $77.9 \pm 0.4 \mathrm{ka}$, and $77.2 \pm 2.5 \mathrm{ka}$. These ages agree with the single AS age reported by Harmon et al. (1983) for a coral from this deposit, and also show that the Bermuda corals grew during the same $\sim 80$ ka highstand as those from the Florida Keys.

A Siderastrea coral from the Devonshire member (the marine facies of the Rocky Bay Formation) at Grape Bay gave a ${ }^{230} \mathrm{Th} / \mathrm{U}$ age of $116.1 \pm 2.4 \mathrm{ka}$, has a calculated initial ${ }^{234} U /{ }^{238} U$ indistinguishable from that of modern sea water (Table 1), and agrees with AS ages of $124 \pm 6 \mathrm{ka}$ and $124 \pm 12 \mathrm{ka}$ for Diploria strigosa corals analyzed by Harmon et al. (1983) from the same locality. At this locality, thin marine deposits of the Devonshire member of the Rocky Bay Formation are overlain by an eolianite facies of this formation. The two members are separated by a weakly developed paleosol only in the back-beach area. The paleosol is so minimally developed that it implies only a very short hiatus in sedimentation between the marine and eolian facies in the back-beach area; elsewhere, the two members are conformable.

\section{IMPLICATIONS FOR SEA LEVEL AT 80 KA}

The new ${ }^{230} \mathrm{Th} / \mathrm{U}$ data and geologic setting of our samples allow estimates of the position of sea level at $\sim 80 \mathrm{ka}$ from tectonically stable platforms. Off the Florida Keys, the reported depth of the topographic crest of the main reef body (Lidz et al., 1991) is
TABLE 1. ISOTOPIC AND AGE DATA FOR CORALS

\begin{tabular}{|c|c|c|c|c|c|c|c|}
\hline Sample* & Genus $^{\dagger}$ & $\begin{array}{l}\text { Age }^{\S} \\
\text { (ka) }\end{array}$ & $\underset{(\mathrm{ppm})}{\mathrm{U}}$ & $\begin{array}{l}\text { Th } \\
(\mathrm{ppb})\end{array}$ & ${ }^{4} U^{/ 238} U^{* *}$ & ${ }^{30} \mathrm{Th} /{ }^{238} \mathrm{U}^{* *}$ & $\begin{array}{l}{ }^{34} \mathrm{U}^{/ 238} \mathrm{U}^{* *} \\
\text { (initial) }\end{array}$ \\
\hline \multicolumn{8}{|l|}{ Bermuda, } \\
\hline SB-1 \#1 & $O c$ & $2.11 \pm 1.10$ & 3.05 & 0.79 & $1.1499(20)$ & $0.0221(110)$ & $1.1508(20)$ \\
\hline SB-1 \#2 & $\mathrm{Oc}$ & $2.15 \pm 0.26$ & 3.14 & 0.34 & $1.1445(26)$ & $0.0224(27)$ & $1.1454(27)$ \\
\hline SB-2 \#1 & $\mathrm{Si}$ & $1.82 \pm 0.44$ & 2.87 & 4.78 & $1.1460(24)$ & $0.0194(45)$ & $1.1468(24)$ \\
\hline SB-2 \#2 & $\mathrm{Si}$ & $1.50 \pm 0.12$ & 2.86 & 4.44 & $1.1459(16)$ & $0.0161(10)$ & $1.1465(16)$ \\
\hline
\end{tabular}

Southampton

Formation:

FSC-4

FSC-5

FSC-6

$\begin{array}{lllll}\mathrm{Oc} & 82.4 \pm 0.9 & 2.47 & 0.62 & 1.1163(19) \\ \mathrm{Oc} & 77.9 \pm 0.4 & 2.98 & 0.44 & 1.1161(16) \\ \mathrm{Oc} & 77.2 \pm 2.5 & 2.98 & 1.48 & 1.1181(28) \\ \mathrm{Oc} & 82.3 \pm 3.6 & 2.77 & 3.27 & 1.1195(29)\end{array}$

$0.5996(45)$

$1.1468(24)$

Bermuda

Rocky Bay

Formation:

GB-2

Florida:

FL-31

FL-32

FL-33

FL-23

FL-20

$\begin{array}{lllllll}\mathrm{Si} & 116.1 \pm 2.4 & 3.80 & 3.01 & 1.1072(29) & 0.7373(83) & 1.1489(41) \\ \mathrm{Si} & <1.0 & 2.66 & 0.41 & 1.1441(22) & <0.011 & 1.1441(23) \\ \mathrm{Ap} & 8.16 \pm 0.10 & 3.31 & 0.24 & 1.1446(10) & 0.0829(10) & 1.1479(11) \\ \mathrm{Ma} & 86.6 \pm 0.9 & 2.27 & 0.15 & 1.1356(12) & 0.6320(43) & 1.1733(16) \\ \mathrm{Ma} & 80.9 \pm 1.7 & 2.71 & 0.21 & 1.1146(20) & 0.5912(84) & 1.1441(27) \\ \mathrm{Ma} & 83.2 \pm 0.9 & 2.99 & 0.17 & 1.1192(21) & 0.6056(42) & 1.1509(27)\end{array}$

${ }^{*} \mathrm{FSC}=$ Fort St. Catherine, GB = Grape Bay, SB = Shelly Bay; sample size $\sim 120 \mathrm{mg}$.

$\dagger \mathrm{Oc}=$ Oculina, $\mathrm{Si}=$ Siderastrea, $\mathrm{Ma}=$ Montastrea annularis, $\mathrm{Ap}=$ Acropora palmata .

$\S_{\text {Ages calculated using half-lives for }}{ }^{230} \mathrm{Th}$ and ${ }^{234} \mathrm{U}$ of 75,380 and $244,600 \mathrm{yr}$, respectively, and include a neglible to very small correction for a secular-equilibrium detrital component with ${ }^{232} \mathrm{Th} / 238 \mathrm{U}=3.8$.

** Activity ratios, calculated from the atomic ratios by normalizing to a secular equilibrium standard, assuming the above half lives. Numbers in parantheses are $2 \sigma$ errors of the leastsignificant digits.

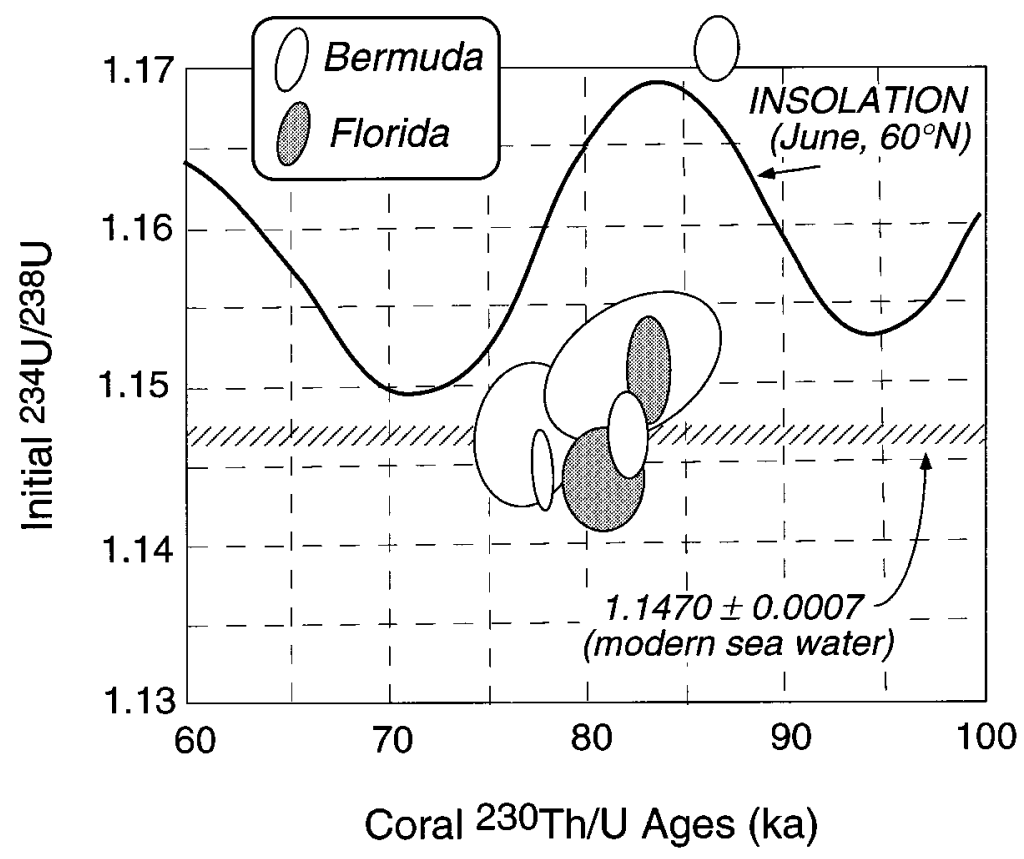

Figure 4. Calculated initial ${ }^{234} \mathrm{U} /{ }^{238} \mathrm{U}$ (activity) for $\sim 80$ ka corals from Florida and Bermuda, plotted against their ${ }^{230} \mathrm{Th} / \mathrm{U}$ ages (shown by their $2 \sigma$ error ellipses). Diagonal-rule band shows initial ${ }^{234} \mathrm{U} /{ }^{238} \mathrm{U}$ of modern sea water, taken as mean and $\mathbf{9 5 \%}$ confidence limit for $\mathbf{2 7}$ Holocene corals analyzed in our laboratory. Curved line shows relative insolation values for 60-100 ka (Berger and Loutre, 1991). 
10-12 m. Montastrea grows over a considerable depth range down to $80 \mathrm{~m}$, but has optimum growth depths of 3-45 m (Shinn et al., 1989). If we assume conservatively that the Montastrea dated in the present study grew in water depths as shallow as $3 \mathrm{~m}$, the $10-12 \mathrm{~m}$ depth of the submerged reef implies a sea level no lower than -7 to $-9 \mathrm{~m}$, relative to present, at $\sim 80 \mathrm{ka}$. Sea level could have been much higher if the corals grew in water deeper than $3 \mathrm{~m}$, which is likely.

The paleo-sea-level significance of the marine deposits at Fort St. Catherine has been controversial. Harmon et al. (1983) interpreted the sediments to be storm generated and concluded that despite their AS ${ }^{230} \mathrm{Th} / \mathrm{U}$ age of $85 \pm 12 \mathrm{ka}$ for an Oculina coral, the sediments provided no constraints on sea level at $\sim 80 \mathrm{ka}$. However, Vacher and Hearty (1989) noted that storm waves likely would have had to traverse an outer reef, followed by a 15-20 km passage through an 11-15-m-deep lagoon on the Bermuda Platform before reaching the vicinity of Fort St. Catherine. In addition, they reported amino-acid ratios for mollusks in marine facies of the Southampton Formation at two other localities on Bermuda that correlate these deposits with those at Fort St. Catherine. Vacher and Hearty (1989) observed that the marine deposits at Fort St. Catherine do not appear in any way different from those of older marine deposits such as the Rocky Bay Formation and the Belmont Formation. We also see no significant difference between the sequence of depositional events at Grape Bay during the 116$124 \mathrm{ka}$ highstand and the sequence at Fort St. Catherine during the $\sim 80$ ka sea-level highstand. Thus, we agree with the conclusions of Vacher and Hearty (1989) that the marine facies at Fort St. Catherine and correlative sediments elsewhere on Bermuda imply a sea level close to, or above, that of the present at $\sim 80 \mathrm{ka}$.

\section{CONCLUSIONS}

Our conclusions have important implications for the history of late Quaternary sea level. An $80 \mathrm{ka}$ sea level close to the present, derived from tectonically stable platforms, conflicts with estimates of -10 to $-20 \mathrm{~m}$ derived from tectonically rising New Guinea and Barbados (Chappell and Shackleton, 1986; Bender et al., 1979; Gallup et al., 1994). The results also conflict with speleothem records from the Bahamas, where sea level at $\sim 80 \mathrm{ka}$ is estimated to be lower than -15 to $-18 \mathrm{~m}$, based on what is interpreted to be continuous subaerial calcite growth during this period (Richards et al., 1994; Lundberg and Ford, 1994). Our studies provide no evidence for the drastic drop in sea level to -60 to $-70 \mathrm{~m}$ implied by the $\mathrm{Mg} / \mathrm{Ca}$ record in ostracodes (Dwyer et al., 1995). The difference in ice volume between most previous sea-level estimates and the present study is greater than the volume of the Greenland ice sheet $(7 \mathrm{~m}$ sea-level equivalent) or West Antarctic ice sheet (5-10 m sea-level equivalent). However, our hypothesis of an $\sim 80 \mathrm{ka}$ sea level close to the present agrees with marine records from the tectonically stable Atlantic Coastal Plain of the United States (Szabo, 1985) and the slowly rising Pacific coast of North America (Muhs et al., 1994), and is close to an independently calculated estimate from New Guinea by Bloom and Yonekura (1985, 1990). Comparison of our ages with highlatitude insolation values indicates that the sea-level stand at $\sim 80 \mathrm{ka}$ could have been orbitally forced.

\section{ACKNOWLEDGMENTS}

Supported by the Global Change and Climate History Program of the U.S. Geological Survey, and a contribution to the LITE (Last Interglacial: Timing and Environment) Project. Part of Muhs's field work in Bermuda was supported by the National Geographic Society. We thank H. L. Vacher and S. R. Herwitz for helpful discussions of Bermuda geology, and A. L. Bloom, N. P. James, B. J. Szabo, and B. H. Lidz for helpful comments on an earlier version of the paper.

\section{REFERENCES CITED}

Bender, M. L., Fairbanks, R. G., Taylor, F. W., Matthews, R. K., Goddard, J. G., and Broecker, W. S., 1979, Uranium-series dating of the Pleistocene reef tracts of Barbados, West Indies: Geological Society of America Bulletin, Part I, v. 90, p. 577-594.

Berger, A., and Loutre, M. F., 1991, Insolation values for the climate of the last 10 million years: Quaternary Science Reviews, v. 10, p. 297-317.

Bloom, A. L., and Yonekura, N., 1985, Coastal terraces generated by sea-level change and tectonic uplift, in Woldenberg, M. J., ed., Models in geomorphology: Winchester, Massachusetts, Allen and Unwin Inc., p. 139-153.

Bloom, A. L., and Yonekura, N., 1990, Graphic analysis of dislocated Quaternary shorelines, in Geophysics Study Committee, eds., Sealevel change: Washington, D.C., National Academy Press, p. 104-115.

Chappell, J., and Shackleton, N. J., 1986, Oxygen isotopes and sea level: Nature, v. 324, p. $137-140$.

Chen, J. H., Edwards, R. L., and Wasserburg, G. J., 1986, ${ }^{238} \mathrm{U},{ }^{234} \mathrm{U}$, and ${ }^{232} \mathrm{Th}$ in seawater: Earth and Planetary Science Letters, v. 80, p. 241-251.

Dwyer, G. S., Cronin, T. M., Baker, P. A., Raymo, M. E., Buzas, J. S., and Correge, T., 1995, North Atlantic deepwater temperature change during late Pliocene and late Quaternary climatic cycles: Science, v. 270, p. 1347-1351.

Gallup, C. D., Edwards, R. L., and Johnson, R. G., 1994, The timing of high sea levels over the past 200,000 years: Science, v. 263, p. $796-800$.

Harmon, R. S., and eight others, 1983, U-series and amino-acid racemization geochronology of Bermuda: Implications for eustatic sea- level fluctuation over the past 250,000 years: Palaeogeography, Palaeoclimatology, Palaeoecology, v. 44, p. 41-70.

Hearty, P. J., Vacher, H. L., and Mitterer, R. M., 1992, Aminostratigraphy and ages of Pleistocene limestones of Bermuda: Geological Society of America Bulletin, v. 104, p. $471-480$

Lidz, B. H., Hine, A. C., Shinn, E. A., and Kindinger, J. L., 1991, Multiple outer-reef tracts along the south Florida bank margin: Outlier reefs, a new windward-margin model: Geology, v. 19, p. 115-118.

Ludwig, K. R., Simmons, K. R., Szabo, B. J., Winograd, I. J., Landwehr, J. M., Riggs, A. C., and Hoffman, R. J., 1992, Mass-spectrometric ${ }^{230} \mathrm{Th}^{-234}{ }^{23} \mathrm{U}-{ }^{238} \mathrm{U}$ dating of the Devils Hole calcite vein: Science, v. 258, p. 284-287.

Lundberg, J., and Ford, D. C., 1994, Late Pleistocene sea level change in the Bahamas from mass spectrometric U-series dating of submerged speleothem: Quaternary Science Reviews, v. 13, p. 1-14.

Milankovitch, M. M., 1941, Canon of insolation and the Ice Age problem: Beograd, Koniglich Serbische Akademie (English translation by the Israel Program for Scientific Translations, Jerusalem, Israel, 1969).

Mix, A. C., 1987, The oxygen-isotope record of glaciation, in Ruddiman, W. F., and Wright, H. E., Jr., eds., North America and adjacent oceans during the last deglaciation: Boulder, Colorado, Geological Society of America, Geology of North America, v. K-3, p. 111-135.

Muhs, D. R., Kennedy, G. L., and Rockwell, T. K. 1994, Uranium-series ages of marine terrace corals from the Pacific coast of North America and implications for last-interglacial sea level history: Quaternary Research, v. 42, p. $72-87$.

Richards, D. A., Smart, P. L., and Edwards, R. L., 1994, Maximum sea levels for the last glacial period from U-series ages of submerged speleothems: Nature, v. 367, p. 357-360.

Ruddiman, W. F., 1987, Synthesis; the ocean ice/ sheet record, in Ruddiman, W. F., and Wright, H. E., Jr., eds., North America and adjacent oceans during the last deglaciation: Boulder, Colorado, Geological Society of America, Geology of North America, v. K-3, p. 463-478.

Shinn, E. A., Lidz, B. H., Kindinger, J. L., Hudson, J. H., and Halley, R. B., 1989, Reefs of Florida and the Dry Tortugas: A guide to the modern carbonate environments of the Florida Keys and the Dry Tortugas: St. Petersburg, Florida, U.S. Geological Survey, 53 p.

Szabo, B. J., 1985, Uranium-series dating of fossi corals from marine sediments of southeastern United States Atlantic coastal plain: Geological Society of America Bulletin, v. 96, p. 398-406.

Vacher, H. L., and Hearty, P., 1989, History of stage 5 sea level in Bermuda: Review with new evidence of a brief rise to present sea level during substage 5a: Quaternary Science Reviews, v. 8, p. 159-168.

Vacher, H. L., Rowe, M., and Garrett, P., 1989, The geological map of Bermuda: Hamilton, Bermuda, Public Works Department, scale 1: 25000.

Manuscript received August 25, 1995

Revised manuscript received December 15, 1995

Manuscript accepted December 22, 1995 